\title{
SUPT5H wt Allele
}

National Cancer Institute

\section{Source}

National Cancer Institute. SUPT5H wt Allele. NCI Thesaurus. Code C53095.

Human SUPT 5H wild-type allele is located in the vicinity of $19 q 13$ and is approximately 31 $\mathrm{kb}$ in leng th. This allele, which encodes transcription elong ation factor SPT 5 protein, is involved in both the modulation of transcript elong ation by RNA polymerase II and the maturation of mRNAs through 7-methylguanosine capping. 